\title{
Pathophysiology and Clinical Manifestations of the $\beta$-Thalassemias
}

\author{
Arthur W. Nienhuis ${ }^{1}$ and David G. Nathan ${ }^{2}$ \\ ${ }^{1}$ Department of Hematology, St. Jude Children's Research Hospital, Memphis, Tennessee 38105 \\ ${ }^{2}$ Department of Pediatric Oncology, Dana-Farber Cancer Institute, and the Division of Hematology and \\ Oncology, Childrens Hospital, Boston, Massachusetts 02215 \\ Correspondence: arthur.nienhuis@stjude.org
}

The $\beta$-thalassemia syndromes reflect deficient or absent $\beta$-globin synthesis usually owing to a mutation in the $\beta$-globin locus. The relative excess of $\alpha$-globin results in the formation of insoluble aggregates leading to ineffective erythropoiesis and shortened red cell survival. A relatively high capacity for fetal hemoglobin synthesis is a major genetic modifier of disease severity, with polymorphisms in other genes also having a significant role. Iron overload secondary to enhanced absorption and red cell transfusions causes an increase in liver iron and in various other tissues, leading to endocrine and cardiac dysfunction. Modern chelation regimens are effective in removing iron and preserving or restoring organ function.

$T_{\mathrm{o}}^{\mathrm{h}}$ $\beta$-thalassemias are genetic disorders of hemoglobin synthesis characterized by deficient $\left(\beta^{+}\right)$or absent $\left(\beta^{0}\right)$ synthesis of the $\beta$ globin subunit of hemoglobin molecule (Weatherall and Clegg 2001). The vast majority of individuals with thalassemia inherit their disorder as a Mendelian recessive. Heterozygous individuals have mild anemia and microcytosis and are categorized as having thalassemia minor or trait, and homozygous individuals have severe anemia of varying degrees and are characterized as having homozygous $\beta$-thalassemia or thalassemia major or intermedia, as discussed in detail below. Much rarer is a dominantly inherited $\beta$ thalassemia in which disease occurs in heterozygous individuals because of synthesis of a highly unstable $\beta$-globin variant (Thein 1999). Usually the disturbance is only in $\beta$-globin synthesis, but rare deletional mutations may remove one or more of the other genes on chromosome 11, resulting in forms of the disease characterized as $\delta \beta-, \gamma \delta \beta$-, or $\varepsilon \gamma \delta \beta$-thalassemia.

\section{HETEROZYGOUS $\boldsymbol{\beta}$-THALASSEMIA}

The hematological features of thalassemia trait are microcytosis, hypochromia, and usually an increase in the percentage of $\mathrm{HbA}_{2}$. The hemoglobin composition is $92 \%-95 \% \mathrm{HbA},>3.8 \%$ $\mathrm{HbA}_{2}$, and variable amounts of $\mathrm{HbF}$ amounting to $0.5 \%-4 \%$. In addition to microcytosis and hypochromia, there is marked variation in size and shape of red blood cells with the red cells of $\beta^{0}$-thalassemia trait having a lower mean

Editors: David Weatherall, Alan N. Schechter, and David G. Nathan

Additional Perspectives on Hemoglobin and Its Diseases available at www.perspectivesinmedicine.org

Copyright (C) 2012 Cold Spring Harbor Laboratory Press; all rights reserved; doi: 10.1101/cshperspect.a011726

Cite this article as Cold Spring Harb Perspect Med 2012;2:a011726 
A.W. Nienhuis and D.G. Nathan

corpuscular volume than those of $\beta^{+}$-thalassemia trait (Cao and Galanello 2010). Historically, the mild anemia with microcytic, hypochromic red cells characteristic of thalassemia trait has been thought to lack clinical consequences other than its association with the anemia of pregnancy (White et al. 1985). However, a recently controlled trial performed in Sri Lanka suggested that individuals with thalassemia trait may experience symptoms of anemia including headache, lethargy, fatigue, dizziness, and exercise intolerance despite having hemoglobin levels that overlap the normal range (Premawardhena et al. 2008). There was no difference in the frequency of these symptoms between the two groups that had either mild anemia or hemoglobin levels in the normal range. There was also a significant increase in frequency of infectious episodes in individuals with $\beta$-thalassemia trait. Men but not women with thalassemia trait have a reduced frequency of advanced coronary artery disease, and myocardial infarction occurs at an older age in men with thalassemia trait (Tassiopoulos et al. 2005).

\section{HOMOZYGOUS $\boldsymbol{\beta}$-THALASSEMIA}

The clinical spectrum of patients with homozygous $\beta$-thalassemia is highly variable (Weatherall and Clegg 2001; Cao and Galanello 2010). Many individuals present with severe anemia early in life and remain transfusion dependent for their entire lives. Such individuals carry the diagnosis of thalassemia major. Others with homozygous $\beta$-thalassemia present with milder anemia and never require transfusion, and some have variable degrees of anemia and may require transfusion intermittently. Such individuals are designated as having thalassemia intermedia. The degree of anemia in those with thalassemia intermedia is from nearly normal levels to sufficiently severe anemia to require occasional blood transfusions. Erythroid hyperplasia leads to medullary expansion with facial deformity and osteoporosis, which may be quite severe. Extramedullary hematopoiesis results in enlargement of the liver and spleen and paraspinal and pulmonary masses of erythroid cells. Diagnostic criteria for the major versus the in- termedia syndrome are rather ill defined and are largely based on the hemoglobin level without transfusion. Generally, a cutoff of $7 \mathrm{~g} / \mathrm{dL}$ is used to distinguish between the two forms, but this criterion is confounded by the fact that the severity of the anemia and associated splenomegaly and defective development may vary in individual patients at different times, and the use of transfusion is partly based on socioeconomic issues as well as access to an adequate blood supply. As noted in a definitive review of this topic, the remarkable phenotypical diversity of $\beta$-thalassemias reflects the heterogeneity of mutations of the $\beta$-globin locus, the action of many secondary and tertiary modifiers, and a wide range of environmental factors (Weatherall 2001).

\section{HEMOGLOBIN E $\boldsymbol{\beta}$-THALASSEMIA}

Hemoglobin $\mathrm{E}$ has a substitution of lysine for glutamic acid at position 26 of the $\beta$-globin chain. This hemoglobin variant is particularly common in Southeast Asia (Weatherall and Clegg 2001). Both heterozygotes and homozygotes for HbE have hypochromic and microcytic cells, and molecular studies have documented deficient accumulation of the $\beta^{\mathrm{E}}$ mRNA. Molecular analysis indicates that the GAG change to AAG at codon 26, which is responsible for the amino acid substitution, also creates a cryptic splice donor site that slows splicing of intron 1 and results in abnormally spliced mRNA species (Orkin et al. 1982). Double heterozygosity for a $\beta$-thalassemia mutation and the $\beta^{\mathrm{E}}$ mutation account for almost $50 \%$ of the patients with severe $\beta$-thalassemia worldwide. This genotype is particularly common in certain countries in Southeast Asia (Olivieri et al. 2010a). Because of the Asian migration to the United States, this genotype is common where Asians have settled (e.g., California). The phenotype of $\mathrm{HbE}$ $\beta$-thalassemia is highly variable, with many patients remaining largely free of transfusion throughout their lifetime, whereas others are started on transfusion at an early age (Olivieri et al. 2010a). For those for whom transfusions were initiated early in life for unclear reasons, discontinuation of transfusion support may be possible later in life (Olivieri et al. 2010b). Recent 
reviews of the clinical features of $\mathrm{HbE} \beta$-thalassemia summarize the clinical heterogeneity and the approach to management of these patients (Olivieri et al. 2008, 2010b). This condition is discussed in more detail by Fucharoen and Weatherall (2012).

\section{PATHOPHYSIOLOGY}

Erythropoiesis in individuals with $\beta$-thalassemia reflects the consequences of excess, unpaired $\alpha$-globin (Nathan and Gunn 1966; Nathan et al. 1969; Cao and Galanello 2010; Sankaran and Nathan 2010). Indeed, the degree of imbalance in the $\alpha$-globin versus $\beta+\gamma$-globin biosynthetic ratio is the major determinate of disease severity rather than the underproduction of hemoglobin (Weatherall et al. 1965; Bank and Marks 1966; Nathan and Gunn 1966; Nathan et al. 1969; Weatherall 2001; Rund and Rachmilewitz 2005). In $\beta$-thalassemia trait there is a twofold excess in the synthesis of $\alpha$-globin, which is consistent with fairly normal hematopoiesis with only mild microcytosis and hypochromia of the red cells. The $\alpha$ to non- $\alpha$ biosynthetic ratio in individuals with thalassemia intermedia is typically $3-4 / 1$ because residual capacity for $\beta$-globin synthesis along with usually modest but variable $\gamma$-globin synthesis mitigates the consequences of excess $\alpha$-globin production. Individuals with $\beta^{0}$-thalassemia mutations have marked chain biosynthetic imbalance as the underlying basis for their severe phenotype.

Following synthesis, $\alpha$-globin interacts with its molecular chaperone, $\alpha$-hemoglobin stabilizing protein (AHSP), to form a protein complex before it is released to interact with $\beta$-globin in forming the hemoglobin tetramer (Yu et al. 2007; Weiss and dos Santos 2009). AHSP facilitates folding of $\alpha$-globin and prevents the formation of misfolded aggregates. $\alpha$-Globin mutations that impair interaction with AHSP are associated with microcytosis and anemia in humans (Yu et al. 2009). Loss of AHSP has also been shown to impair erythropoiesis in a mouse model of $\beta$-thalassemia (Kong et al 2004). Evidence suggests that AHSP levels may influence the phenotype of $\beta$-thalassemia (Lai et al. 2006).
Once the capacity of AHSP is exceeded, $\alpha$ globin forms molecular aggregates, which precipitate, forming inclusions that damage the cell membrane and the membranes of intracellular organelles (Fig. 1). Aggregated $\alpha$-chains also trigger the formation of reactive oxygen species, which further damage the protein and lipid constituents of cell membranes. As well as heme and iron, one of the most toxic products of unpaired $\alpha$-chains is hemichromes, which bind to the membrane and promote clustering of band 3, one of its major constituents (Rund and Rachmilewitz 2005). The formation of $\alpha$ chain inclusions occurs early during erythropoiesis and peaks in the polychromatophilic erythroblasts, leading to cellular apoptosis (Mathias et al. 2000). Thus, anemia in the severe $\beta$ thalassemias reflects both ineffective erythropoiesis as well as shortened red cell survival as a consequence of $\alpha$-globin inclusions (Nathan and Gunn 1966; Nathan et al. 1969). The pathophysiology of $\beta$-thalassemia has been compared with other disorders such as Parkinson's disease and Huntington's disease, which are caused by accumulations of unstable, aggregation-prone proteins (Khandros and Weiss 2010; Khandros et al. 2011). Almost all cells have some capacity to detoxify and remove damaging proteins via multiple biochemical pathways termed protein quality control (PQC). The ubiquitinproteasome system (UPS) and the lysosomeautophagy pathways that function in PQC are thought to participate in the degradation of $\alpha$ globin, but the capacities of these pathways are exceeded in the erythroid cells of individuals with the severe forms of $\beta$-thalassemia.

\section{GENETIC MODIFIERS}

The thalassemias are heterogeneous at the molecular level, with more than 200 disease-causing mutations having been identified (Weatherall 2001; Rund and Rachmilewitz 2005; Cao and Galanello 2010; Thein 2013). Alleles characterized by a mild phenotype typically include promoter mutations, although splicing and frameshift mutations have also been discovered in individuals homozygous for $\beta$-thalassemia but having a mild phenotype. Coinheritance of an $\alpha$ - 
A.W. Nienhuis and D.G. Nathan

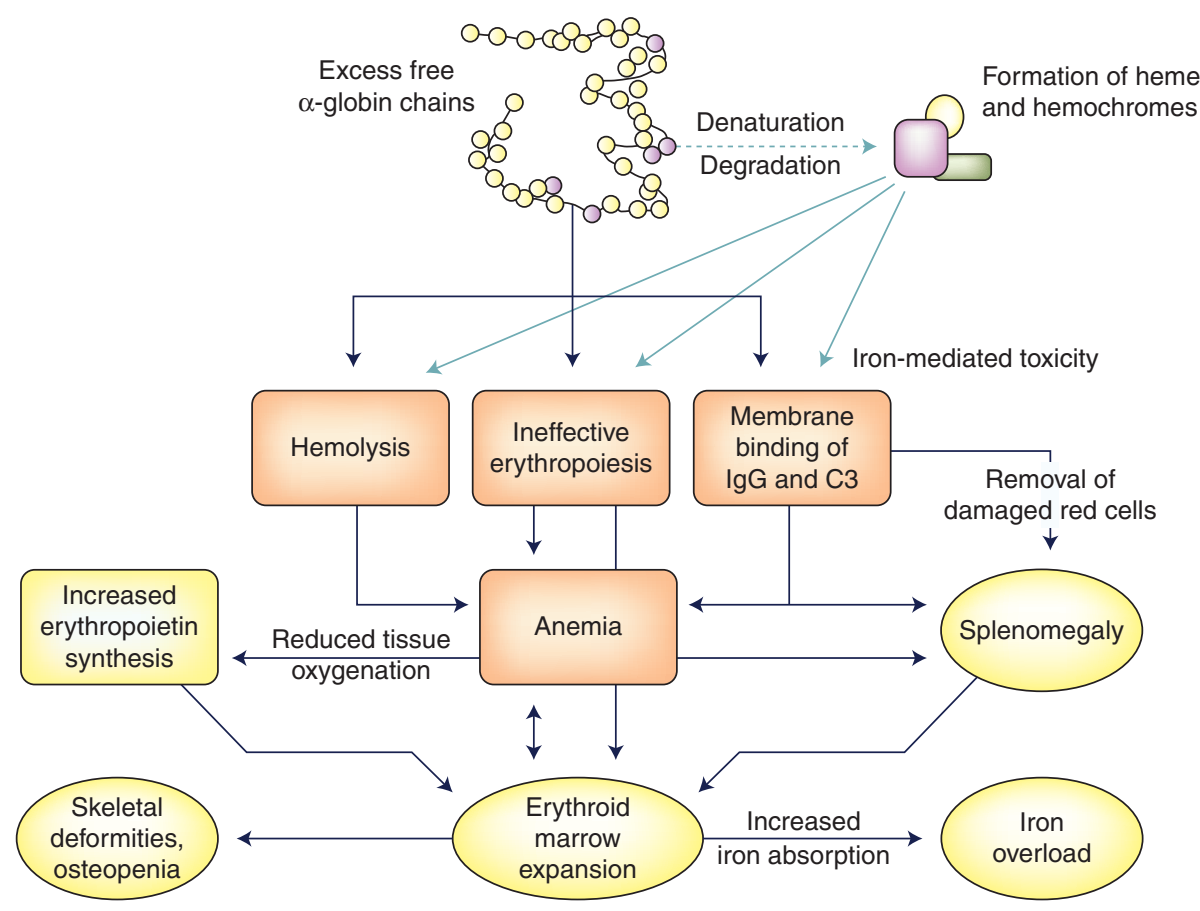

Figure 1. Pathophysiology of $\beta$-thalassemia. Because of the imbalance in chain synthesis, an excess of freed $\alpha$ globin chains accumulates within erythroid cells. Aggregation, denaturation, and degradation of these chains leads to the formation of insoluble precipitates as well as hemichromes, which damage cell membranes. Membrane damage leads to ineffective erythropoiesis within the bone marrow, hemolysis of red cells within the circulation, and binding of immunoglobulin and complement components to red cell membranes, triggering loss of red cells in the spleen. The resulting anemia leads to diminished tissue oxygenation, an increase in erythropoietin levels, and further stimulation of the bone marrow. Bone marrow expansion causes skeletal deformities and osteopenia. Substances released from degenerating red cells increase iron absorption, which contributes to iron overload.

thalassemia gene is another mechanism that mitigates the phenotype of homozygous $\beta$-thalassemia (Kan and Nathan 1970; Wainscoat et al. 1983; Cao et al. 1994). Individuals doubly heterozygous for $\alpha$ - and $\beta$-thalassemia have microcytosis but essentially normal circulating hemoglobin concentrations. Individuals homozygous for $\beta$-thalassemia who inherit a chromosome having a single $\alpha$-globin gene deletion may have a milder phenotype, whereas deletion of both $\alpha$-globin genes on one chromosome is typically associated with thalassemia intermedia. Another mechanism for thalassemia intermedia is heterozygous $\beta$-thalassemia inherited along with either triplicated $\alpha$-globin gene arrangement or with homozygosity for a triplicated globin gene arrangement (Premawardhena et al. 2005).

Fetal hemoglobin is a much more common and major modifier of disease severity in individuals with $\beta$-thalassemia. In normal individuals, $\mathrm{HbF}$ synthesis occurs in a minority of erythroid cells. Only $5 \%-8 \%$ of red cells, called F cells, contain $\mathrm{HbF}$, amounting to $5 \%-20 \%$ of the total hemoglobin in those cells (Boyer et al. 1975). In the context of a severe deficiency of $\beta$ globin synthesis, even the low levels of $\gamma$-globin in $\mathrm{F}$ cells reduce the relative excess of $\alpha$-globin and provide a potent selective survival advantage for cells making $\mathrm{HbF}$ in the context of the ineffective erythropoiesis characteristic of the most severe forms of $\beta$-thalassemia. This selective 
survival is thought to account for the elevated levels of fetal hemoglobin percentage in a significant majority of patients who are homozygous for $\beta$-thalassemia (Gabuzda et al. 1962; Weatherall 2001). Certain $\beta$-globin promoter mutations are associated with increased $\gamma$-chain synthesis from the same chromosome (Cao and Galanella 2010). The number of F cells in normal individuals, and presumably those with $\beta$ thalassemia, is under genetic control and varies among individuals (Galarneau et al. 2010). Presumably having F-cell numbers at the higher range of normal is associated with a milder clinical phenotype. Study of a large pedigree has shown that coinheritance of an HPFH gene is associated with higher mean corpuscular hemoglobin, mean corpuscular volume, and $\mathrm{HbA}_{2}$ levels (Garner et al. 2003). A recent study in untransfused patients with thalassemia intermedia has documented an inverse correlation between $\mathrm{HbF}$ levels and the frequencies of morbidities reflecting disease severity (Musallam et al. 2012). Hydroxyurea has been reported to increase $\mathrm{HbF}$ in some untransfused patients with severe $\beta$-thalassemia and to reduce the transfusion requirement in a minority of patients on regular transfusions (Karimi et al. 2011). A favorable response to hydroxyurea may be more frequent in thalassemic individuals with certain haplotypes (Italia et al. 2009).

Hereditary persistence of $\mathrm{HbF}(\mathrm{HPFH})$ was initiallyobserved more than 50 years ago (Weatherall and Clegg 2001). Recent molecular studies have shown that HPFH may result from deletion mutations or point mutations within the $\beta$-globin gene cluster. Deletion mutations involving the $\delta$ - and $\beta$-globin genes may cause the phenotype of $\delta \beta$-thalassemia, characterized by microcytosis and heterocellular distribution of $\mathrm{HbF}$, or be associated with increased production of $\mathrm{HbF}$ in a pancellular distribution with morphologically normal red cells, the phenotype of HPFH. Recent characterization of several deletional mutations in individuals with either the HPFH phenotype or the phenotype of $\delta \beta$ thalassemia has identified a functional element within a $3.5-\mathrm{kb}$ region between the ${ }^{\mathrm{A}} \gamma$ - and $\delta$ globin genes that, when present, results in relative silencing of the $\gamma$-globin genes and the $\gamma \beta$ - thalassemia phenotype and, when absent, allows higher levels of $\mathrm{HbF}$ expression and the HPFH phenotype (Sankaran et al. 2011). This region includes sites for binding of the transcription factor BCL11A. Alternatively, augmentation of $\mathrm{HbF}$ production may reflect a single nucleotide polymorphism (SNP) in one of the $\gamma$-globin gene promoters or elsewhere in the globin locus, which leads to overexpression of the cognate gene. Among the most common is an SNP at -158 bp of the ${ }^{\mathrm{G}} \gamma$ gene promoter that creates an XMNI site polymorphism. Detailed linkage analysis has shown that this SNP is not the actual causal mechanism of HPFH, but, rather, augmentation of ${ }^{\mathrm{G}} \gamma$ gene expression occurs as a consequence of an SNP in linkage disequilibrium with the aforementioned Xmn-1 site located midway between ${ }^{\mathrm{A}} \gamma$ - and $\delta$-globin genes, which may affect BCL11A binding (Galarneau et al. 2010). Fetal hemoglobin is normal in normal subjects and in $\beta$-thalassemia heterozygotes with this polymorphism, but the variant leads to increased production during hematopoietic stress such as occurs in homozygous $\beta$-thalassemia (Labie et al. 1985). Another HPFH SNP, a substitution at $-96 \mathrm{bp}$ of the ${ }^{\mathrm{A}} \gamma$ promoter, has been found linked to a nonsense mutation in the $\beta$-globin gene in individuals with Sardinian $\beta$ thalassemia (Pirastu and Kan 1984). Homozygotes for this combination of mutations are clinically normal other than having predominantly $\mathrm{HbF}$ in their red cells.

In addition to SNPs within the $\beta$-globin locus, genome-wide association studies (GWAS) have identified additional loci that can contribute significantly to the variation in $\mathrm{HbF}$ levels (Garner et al. 2000; Uda et al. 2008; Galarneau et al. 2010). An SNP in the BCL11A gene has been shown to contribute to the level of $\mathrm{HbF}$ expression. As discussed by Sankaran and Orkin (2013), functional studies have shown that BCL11A is a significant component of the silencing mechanism that turns off the $\gamma$-globin genes (Sankaran et al. 2009). Suppression of BCL11A levels in cultured thalassemic erythroid cells markedly increases $\mathrm{HbF}$ production (Wilber et al. 2011a). Experimental evidence shows correction of sickle cell disease in a mouse model by suppression of Bcllla (Xu et al. 2011). BCL11A 
A.W. Nienhuis and D.G. Nathan

binds several points in the region between the ${ }^{A} \gamma$ - and $\delta$-globin genes including within the critical region that differentiates HPFH from $\delta \beta$-thalassemia deletions (Sankaran et al. 2011). The other locus that has been implicated in modulating HbF levels is MYB (Galarneau et al. 2010). An SNP in what is thought to be a regulatory region near the gene is associated with differences in the level of MYB expression. Individuals with lower levels of MYB have higher $\mathrm{HbF}$ levels than individuals with higher MYB levels. In another study, a 3-bp deletion in an intragenic region near the MYB gene with enhancer-like activity was associated with higher HbF levels (Farrell et al. 2011). Variants in both the BCL11A and MYB loci have been shown to modify disease severity in individuals homozygous for Sardinian $\beta^{0}$-thalassemia (Galanello et al. 2009). Other transcription factors, including KLF1, have been implicated in regulation of HbF levels (for review, see Wilber et al. 2011b). KLF1 may mediate its effects on HbF through a dual mechanism acting both on the $\beta$-globin and BCL11A promoters.

Individuals with thalassemia have hyperbilirubinemia secondary to ongoing hemolysis and ineffective erythropoiesis. Iron loading occurs because of increased iron absorption as well as the administration of blood transfusions. Osteoporosis is common, potentially secondary to hypogonadism and other endocrine abnormalities as well as expansion of marrow cavities. Increased susceptibility to infection is also characteristic of the severe forms of $\beta$-thalassemia. Genetic polymorphisms in various genes involved with these clinical features have been described as acting as tertiary modifiers of the phenotype of thalassemia (Weatherall 2001).

\section{IRON OVERLOAD}

Patients with the more severe forms of $\beta$-thalassemia, both intermedia and major, have increased tissue deposition of iron. Senescence of transfused red cells in patients with transfusiondependent $\beta$-thalassemia results in iron deposition within the reticuloendothelial system. As iron overload progresses, deposited iron also appears within the hepatic parenchyma, various endocrine tissues, and, more slowly, in the myocardium.

In normal humans, iron homeostasis is achieved by controlling absorption (see Ganz and Nemeth 2012). Only $\sim 1 \mathrm{mg}$ is lost from the body each day, largely through shedding of the epithelial cells from the intestine, urinary tract, skin, and other mucosal organs. Each milliliter of transfused blood contains $\sim 1 \mathrm{mg}$ of iron, thus receipt of a unit of packed red cells typically results in the deposition of $200 \mathrm{mg}$ of iron ultimately in the tissues following red cell senescence. Lacking excretory mechanisms, individuals with thalassemia who receive blood transfusion inevitably experience significant iron overload.

In individuals with thalassemia intermedia, increased tissue iron occurs as a consequence of occasional transfusions but mainly reflects increased iron absorption (Ginzburg et al. 2011). This paradoxical increase in iron absorption despite systemic iron overload probably reflects release of erythroid factors during the cellular apoptosis associated with ineffective erythropoiesis that inhibit hepcidin production by the liver. Hepcidin is a 25-amino-acid peptide hormone that negatively regulates iron flow into the plasma by inhibiting the absorption of dietary iron, the release of iron from macrophages, and the release of stored iron from hepatocytes (Ganz and Nemeth 2011). Ferric iron exits from cells via the iron exporter ferroportin, a multipass transmembrane protein. Ferroportin is abundant in duodenal enterocytes, in splenic and hepatic macrophages, and in hepatocytes, all cells known to export iron (Ganz and Nemeth 2011). Hepcidin inhibits iron efflux by binding ferroportin and triggering endocytosis of both molecules with subsequent lysosomal degradation (Nemeth et al. 2004). Factors released from apoptotic erythroblasts include growth differentiation factor 15 (GDF15), a member of the transforming growth factor- $\beta$ superfamily (Tanno et al. 2007). Serum from thalassemia patients suppressed the production of hepcidin by primary human hepatocytes, and depletion of GDF15 prevented the hepcidin suppression. A second molecule, named twisted gastrulation (TWSGI), was also shown to be highly expressed 
in erythroblasts and also able to inhibit hepcidin expression in mouse and human erythroid cells (Tanno et al. 2009). The roles of GDF15 and TWSGI remain to be fully defined. The end result of suppression of hepcidin expression is to enhance iron absorption from the intestine and to allow iron release from macrophages. The normal and pathological regulation of hepcidin synthesis has recently been reviewed (Nemeth 2010). Synthetic mini-hepcidins with a longer half-life have been shown to reduce iron absorption in mice after oral administration and have been proposed as potential therapeutic agents in individuals with severe $\beta$-thalassemia (Preza et al. 2011).

Iron released from cells is bound to transferrin and transported to the bone marrow and other tissues, where iron is taken up by the transferrin receptors. Less than $1 \%$ of the total body iron is found in blood at any one time, although up to $25 \mathrm{mg}$ may circulate as transferrin-bound iron throughout the 24-h cycle. The expanded erythropoiesis in individuals with $\beta$-thalassemia results in a dramatic increase in plasma iron turnover of 10-fold to 15-fold over normal (Hershko et al. 2005). Normally, the transferrin saturation is maintained in a relatively low range of $\sim 10 \%-50 \%$. Iron is stored in tissue in the form of ferritin, a multicomponent protein shell that internalizes iron, thereby protecting cellular constituents from potential oxidative damage. Intracellular ferritin iron is in equilibrium with the cytosolic soluble iron pool. Hemosiderin is an insoluble aggregate of iron that forms in lysosomes when ferritin is degraded ( $\mathrm{Wu}$ et al. 2010; Kim et al. 2011). Both ferritin and hemosiderin accumulate in the cells of individuals with severe $\beta$-thalassemia. Accumulation of iron in reticuloendothelial cells is relatively harmless, whereas accumulation of iron in parenchymal tissues may damage critical cells in the heart, endocrine glands, and liver (Hershko et al. 2005).

As a consequence of iron overload in patients with thalassemia either from blood transfusion or excessive absorption or a combination of the two, transferrin saturation increases to $75 \%-100 \%$ and non-transferrin-bound iron (NTBI) is found in the blood (Hershko et al. 1978). NTBI is very heterogeneous and exists in various forms including in complex with citrate and proteins (Evans et al. 2008). Strategies have been devised to detect labile plasma iron (LPI), a fraction of the NTBI pool that is metabolically active in interacting with membrane constituents, leading to membrane damage via the formation of reactive oxygen species (ROS) (Pootrakul et al. 2004; Hershko 2010). Rather than using the transferrin receptor, NTBI enters cells by various cellular channels in forms that have the potential to damage cells (Oudit et al. 2003; Liuzzi et al. 2006). The liver and myocardium clear NTBI at a rate 200-fold that of transferrinbound iron (Oudit et al. 2003, 2006). A portion of the NTBI is accessible to iron chelators directly (Breuer et al. 2001), whereas additional iron may be chelated in the presence of ironmobilizing agents (Esposito et al. 2003). Chelators administered to patients with thalassemia have the potential to reduce NTBI (Porter et al. 1996). Intravenous administration is more effective at reducing NTBI than subcutaneous administration. The reduction and reemergence of NTBI have rather complex kinetics (Porter et al. 1996), although these studies support the use of continuous rather than intermittent chelation in high-risk patients. As discussed in detail below, cardiac myocytes are a critical target for iron-induced ROS. Using an in vitro model of neonatal rat cardiomyocytes, the oral chelators deferasirox and deferiprone were able to effectively access and reduce the intracellular labile iron compartments, whereas desferrioxamine removed iron mainly by eliminating the LPI in plasma (Glickstein et al. 2006). These in vitro studies suggested that the rapid accessibility of oral chelators to intracellular labile iron compartments may render them potentially efficacious for protection and reversal of cardiac damage induced by iron overload (Glickstein et al. 2006).

\section{CLINICAL MANIFESTATIONS}

\section{Anemia}

Classically, individuals with severe $\beta$-thalassemia have presented with variable but often very severe degrees of anemia, expansion of the bone 
marrow spaces secondary to erythroid hyperplasia, hepatosplenomegaly, and extramedullary hematopoiesis in the chest and abdomen. The external appearance is characterized by pallor and slight jaundice, frontal bossing and other abnormalities of the facies secondary to marrow expansion, and abdominal enlargement due to hepatosplenomegaly. Usually, these manifestations are absent or minimally present in patients with thalassemia major if transfusion therapy is initiated early during the first year of life provided that the hemoglobin levels are maintained at $9-10 \mathrm{~g} / \mathrm{dL}$. Where transfusion is readily available, the classical physical findings of thalassemia are now more commonly found in patients with thalassemia intermedia, particularly those who are at the severe end of the phenotypical spectrum. In such patients, the physical manifestations can be suppressed in part with subsequent transfusion. Transfusion practices for thalassemia intermedia vary considerably. Individuals with thalassemia intermedia in developed countries are likely to be transfused, whereas transfusion is used more sparingly in countries where resources are limited (Rachmilewitz and Giardina 2011; Taher et al. 2011). The natural history of thalassemia intermedia is highly variable, although the complications of severe anemia are common (Borgna-Pignatti et al. 2010). Splenectomy may be required because of very large spleen size, with increasing anemia or increasing transfusion requirement with or without a decrease in neutrophil or platelet count.

\section{Iron Overload}

The clinical manifestations of iron overload have come to dominate the clinical phenotype of individuals with severe $\beta$-thalassemia. Cardiac dysfunction is the main clinical problem that may lead to early death. Endocrine abnormalities, particularly hypogonadism, low growth hormone, hypothyroidism, and diabetes mellitus, are also significant problems. Iron deposition of the liver may be substantial, although functional abnormalities are usually mild unless iron overload is very severe. Fortunately chelation therapy prevents and, when given in inten- sive combination therapy, may reverse the complications of iron overload (Farmaki et al. 2010).

\section{Noninvasive Measurement of Tissue Iron}

Hepatic biopsy and measurement of liver iron concentration long remained the gold standard for estimating the degree of iron overload in patients with severe $\beta$-thalassemia. Magnetic susceptibility imaging was the first noninvasive quantitative technique, which established a correlation between liver iron concentration by biopsy and this noninvasive measurement (Brittenham et al. 1982). The instrumentation required for this technique is available in only a few institutions, and therefore this method has not been widely applied. Only when liver iron concentration could be reliably estimated by magnetic resonance imaging (MRI) with clinically available devices that could be standardized from institution to institution, did noninvasive measurement of liver iron supplant hepatic biopsy as the gold standard (Gandon et al. 2004; St Pierre et al. 2005).

MRI has also been applied to estimate cardiac iron. The T2* parameter and its reciprocal 1/R2* have been shown to correlate with the degree of iron overload in the liver and, by extrapolation, to the concentration of iron in the myocardium (Wood 2011). Limited autopsy studies support a direct correlation between chemically determined myocardial iron and MRI measurements (Carpenter et al. 2011). MRI has also been applied to the evaluation of iron deposition in the pituitary gland and the pancreas. Availability of these noninvasive techniques has been useful in determining the relative rate of mobilization of iron from various tissues during chelation therapy. Iron is mobilized more readily from the liver and much more slowly from the heart and endocrine tissues (Wood 2011).

\section{Cardiac Manifestations}

The institution of regular transfusions for patients with thalassemia major prevents the overt consequences of anemia. However, iron accumulation progresses with iron deposition in the myocardium and toxic NTBI in the plasma, 
becoming problematic during the late teenage years or early twenties. Cardiac abnormalities include arrhythmias, both atrial and ventricular, and/or congestive heart failure (Engle 1964). Sudden death often occurred, whereas other patients died of progressive congestive heart failure. Death by the mid twenties was the norm.

This dismal clinical course was modified with the introduction of regular chelation with desferrioxamine, particularly when it was given by continuous subcutaneous infusion over a significant portion of each 24-h period (Propper et al. 1976, 1977; Pippard et al. 1978; Wolfe et al. 1985; Olivieri et al. 1994; Brittenham et al. 1993). Not unexpectedly, compliance with the cumbersome subcutaneous administration via a small infusion pump varied widely among participants, providing an unintended opportunity to compare well-chelated versus poorly chelated individuals (Brittenham et al. 1994; Olivieri et al. 1994). The dramatic reduction in cardiac mortality in well-chelated groups was among the first unequivocal evidence that chelation therapy could modify the clinical phenotype with respect to the cardiac manifestations of iron overload. Subsequent large studies have strongly supported the use of chronic chelation to prevent cardiac death (Borgna-Pignatti et al. 2006; Wood 2011).

Improvement in established cardiac disease was first achieved with continuous interfusion of desferrioxamine (Anderson et al. 2004). Iron was mobilized more readily from the liver than the heart as established by MRI T2* measurements. Some evidence suggests that mobilization of iron from the myocardium is more efficient with the low-molecular-weight chelator deferiprone (Brittenham et al. 2003), and that desferrioxamine and deferiprone administration together are more effective than desferrioxamine alone in reversing cardiac dysfunction as shown in a randomized trial (Tanner et al. 2007). Deferasirox has also been shown to reduce and prevent cardiac iron overload (Pennell et al. 2010, 2011).

Pulmonary hypertension is an increasingly recognized complication in patients with severe $\beta$-thalassemia (Morris and Vichinsky 2010). Advancing age and history of splenectomy are the major risk factors that have been identified. Among the pathophysiological factors are red cell membrane pathology, coagulation abnormalities, platelet activation, oxidative stress, and chronic hemolysis with release of thrombogenic vesicles (Morris and Vichinsky 2010). Although the incidence of pulmonary hypertension is more common in patients with thalassemia intermedia, a recent cross-sectional study showed that pulmonary hypertension may occur in both children and adults with age, splenectomy, hepatitis $\mathrm{C}$ infection, and smoking as significant univariate risk factors (Morris et al. 2011). When present, pulmonary hypertension may contribute to the severity of cardiovascular symptomatology and complicate heart failure due to left ventricular dysfunction.

\section{Endocrine Abnormalities}

Growth retardation secondary in part to growth hormone deficiency and hypogonadism are typically the initial manifestations of iron overload in $\beta$-thalassemic patients (Chatterjee and Bajoria 2010). In unchelated patients, failure to develop secondary sex characteristics during the teenage years was very common. Regular chelation therapy has reduced the incidence of hypogonadism, although hormone replacement is often required (Wood 2011). Well-chelated young men with thalassemia are fertile, although potentially requiring hormonal administration, and women with severe $\beta$-thalassemia may achieve motherhood either with or without obstetrical intervention. Other endocrine complications include impaired glucose tolerance and diabetes (Noetzli et al. 2011), hypothyroidism, hypoparathyroidism, and growth hormone deficiency (Borgna-Pignatti et al. 2004a).

\section{Hepatic Manifestations}

Progressive iron deposition is characteristic in patients with severe $\beta$-thalassemia. Invasive liver biopsies and now non-invasive methodologies (see below) have established the correlation between liver iron concentration and 
A.W. Nienhuis and D.G. Nathan

histological and functional abnormalities. Iron accumulation to the point of $7 \mathrm{mg} / \mathrm{g}$ liver (dry weight) seems well tolerated, but as the liver iron concentration increases with regular transfusion and no or inadequate chelation, fibrosis in the periportal areas and ultimately frank cirrhosis occur. Liver functional abnormalities remain mild until iron overload is severe. Hepatitis $\mathrm{C}$ infection was common before the development of effective screening and potentially accelerated the development of cirrhosis and increased the risk for development of hepatocellular carcinoma (Borgna-Pignotti et al. 2004a; Mancuso 2010). Chelation therapy prevents iron accumulation, although the increased risk of hepatocellular carcinoma as a consequence of hepatic iron overload is not completely eliminated.

\section{Other Complications}

Osteoporosis often occurs in patients with thalassemia, reflecting marrow expansion, endocrine deficiencies, iron toxicity, and the potential toxicity of chelators (Terpos and Voskaridou 2010). Cortical thinning and subclinical fractures as well as problematic clinical fractures may occur, the latter with minimal trauma. A hypercoagulable state, which increases the risk for thromboembolism, has also been described in patients with thalassemia secondary to platelet activation, red cell membrane damage, and endothelial cell activation (Cappellini et al. 2010). Another clinical manifestation is the occurrence of chronic skin ulceration about the ankles secondary to chronic anemia. All of these complications are more common in untransfused patients with thalassemia intermedia than in frequently transfused patients with thalassemia intermedia or patients with thalassemia major who receive regular transfusions (BorgnaPignatti et al. 2010). Nutritional deficiencies are common in individuals with severe $\beta$-thalassemia and may contribute to other complications such as osteoporosis and diabetes mellitus (Fung 2010). The role of inhibitors of osteoclast function in thalassemia is not firmly established, but small trials suggest that such treatment may be useful (Leung et al. 2009).

\section{REFERENCES}

* Reference is also in this collection.

Anderson LJ, Westwood MA, Holden S, Davis B, Prescott E, Wonke B, Porter JB, Walker JM, Pennell DJ. 2004. Myocardial iron clearance during reversal of siderotic cardiomyopathy with intravenous desferrioxamine: A prospective study using T2* cardiovascular magnetic resonance. Br J Haematol 127: 348-355.

Bank A, Marks PA. 1966. Excess $\alpha$ chain synthesis relative to $\beta$ chain synthesis in thalassaemia major and minor. $\mathrm{Na}$ ture 212: $1198-1200$.

Borgna-Pignatti C, Rugolotto S, De Stefano P, Zhao H, Cappellini MD, Del Vecchio GC, Romeo MA, Forni GL, Gamberini MR, Ghilardi R, et al. 2004. Survival and complications in patients with thalassemia major treated with transfusion and deferoxamine. Haematologica 89: 1187-1193.

Borgna-Pignatti C, Cappellini MD, De Stefano P, Del Vecchio GC, Fomi GL, Gamberini MR, Ghilard R, Piga A, Romeo MA, Zhao H, et al. 2006. Cardiac morbidity and mortality in deferoxamine- or deferipronetreated patients with thalassemia major. Blood 107: 3733-3737.

Borgna-Pignatti C, Marsella M, Zanforrin N. 2010. The natural history of thalassemia intermedia. Ann NY Acad Sci 1202: 214-220.

Boyer Sh, Belding TK, Margolet L, Noyes AN. 1975. Fetal hemoglobin restriction to a few erythrocytes ( $F$ cells) in normal human adults. Science 188: 361-363.

Breuer W, Ermers MJ, Pootrakul P, Abramov A, Hershko C, Cabantichik ZI. 2001. Desferrioxamine-chelatable iron, a component of serum non-transferrin-bound iron, used for assessing chelation therapy. Blood 197: 792-798.

Brittenham GM, Farrell DE, Harris JW, Feldman ES, Danish EH, Muir WA, Tripp JH, Bellon EM. 1982. Magnetic-susceptibility measurement of human iron stores. N Engl J Med 307: 1671-1675.

Brittenham GM, Cohen AR, McLaren Ce, Martin MB, Griffith PM, Nienhuis AW, Young NS, Allen CJ, Farrell DE, Harris JW. 1993. Hepatic iron stores and plasma ferritin concentration in patients with sickle cell anemia and thalassemia major. Am J Hematol 42: 81-85.

Brittenham GM, Griffith PM, Nienhuis AW, McLaren CE, Young NS, Tucker EE, Allen CJ, Farrell DE, Harris JW. 1994. Efficacy of deferoxamine in preventing complications of iron overload in patients with thalassemia major. N Engl J Med 1331: 567-573.

Brittenham GM, Nathan DG, Olivieri NF, Pippard MJ, Weatherall DJ. 2003. Deferiprone versus desferrioxamine in thalassaemia and $\mathrm{T} 2^{*}$ validation and utility. Lancet 361: 183.

Cao A, Galanello R. 2010. $\beta$-Thalassemia. Genet Med 12: 61-76.

Cao A, Galanello R, Rosatelli MC. 1994. Genotype-phenotype correlations in $\beta$-thalassemias. Blood Rev 8: 1-12.

Cappellini MD, Motta I, Musallam KM, Taher AT. 2010. Redefining thalassemia as a hypercoagulable state. Ann NY Acad Sci 1202: 231-236.

Carpenter JP, He T, Kirk P, Roughton M, Anderson LJ, de Noronha SV, Sheppard MN, Porter JB, Walker JM, 
Wood JC, et al. 2011. On T2* magnetic resonance and cardiac iron. Circulation 123: 1519-1528.

Chatterjee R, Bajoria R. 2010. Critical appraisal of growth retardation and pubertal disturbances in thalassemia. Ann NY Acad Sci 1202: 100-114.

Engle MA. 1964. Cardiac involvement in Cooley's anemia. Ann NY Acad Sci 119: 694-702.

Esposito BP, Breuer W, Sirankapracha P, Pootrakul P, Hershko C, Cabantchik ZI. 2003. Labile plasma iron in iron overload: Redox activity and susceptibility to chelation. Blood 102: 2670-2677.

Evans RW, Rafique R, Zarea A, Rapisarda C, Cammack R, Evans PJ, Porter JB, Hider RC. 2008. Nature of non-transferrin-bound iron: Studies on iron citrate complexes and thalassemic sera. J Biol Inorg Chem 13: 57-74.

Farmaki T, Tzoumari I, Pappa C, Chouliaras G, Berdoukas V. 2010. Normalisation of total body iron load with very intensive combined chelation reverses cardiac and endocrine complications of thalassaemia major. Br J Haematol 148: $466-475$

Farrell JJ, Sherva RM, Chen Z, Luo H, Chu BF, Ha SY, Li CK, Lee ACW, Li RCH, Li CK, et al. 2011. A 3-bp deletion in the HBSIl-MYB intergenic region of chromosome 6q23 is associated with HbF expression. Blood 117: 4935-4945.

* Fucharoen S, Weatherall DJ. 2012. The hemoglobin E thalassemias. Cold Spring Harb Perspect Med 2: a011734.

Fung EB. 2010. Nutritional deficiencies in patients with thalassemia. Ann NY Acad Sci 1202: 188-196.

Gabuzda TG, Nathan DG, Gardner FH. 1962. Comparative metabolism of haemoglobins $\mathrm{A}$ and $\mathrm{F}$ in thalassaemia. Nature 196: 781-782.

Galanello R, Sanna S, Perseu L, Sollaino MC, Satta S, Lai ME, Barella S, Uda M, Usala G, Abecasis GR, et al. 2009. Amelioration of Sardianian $\beta^{0}$ thalassemia by genetic modifiers. Blood 114: 3935-3937.

Galarneau G, Palmer CD, Sankaran VG, Orkin SH, Hirschhorn JN, Lettre G. 2010. Fine-mapping at three loci known to affect fetal hemoglobin levels explains additional genetic variation. Nat Genet 42: 1049-1051.

Gandon Y, Olivie D, Guyader D, Aube C, Oberti F, Sebille V, Deugnier Y. 2004. Non-invasive assessment of hepatic iron stores by MRI. Lancet 363: 357-362.

Ganz T, Nemeth E. 2011. Hepcidin and disorders of iron metabolism. Аnпu Rev Med 62: 347-360.

* Ganz T, Nemeth E. 2012. Iron metabolism: Interactions with normal and disordered erythropoiesis. Cold Spring Harb Perspect Med 2: a011668.

Garner C, Tatu T, Reittie JE, Littlewood T, Darley J, Cervino S, Farrall M, Kelly P, Spector TD, Thein SL. 2000. Genetic influences on F cells and other hematologic variables: A twin heritability study. Blood 95: 342-346.

Garner C, Dew TK, Sherwood R, Rees D, Thein SL. 2003. Heterocellular hereditary persistence of fetal haemoglobin affects the haematological parameters of $\beta$-thalassemia trail. Br J Haematol 123: 353-358.

Ginzburg Y, Rivella S. 2011. $\beta$-Thalassemia: A model for elucidating the dynamic regulation of ineffective erythropoiesis and iron metabolism. Blood 118: 4321-4330.

Glickstein H, Ben El R, Link G, Breuer W, Konijn AM, Hershko C, Nick H, Cabantchik ZI. 2006. Action of chelators in iron-loaded cardiac cells: Accessibility to intra- cellular labile iron and functional consequences. Blood 108: 3195-3203.

Hershko C. 2010. Pathogenesis and management of iron toxicity in thalassemia. Ann NY Acad Sci 1202: 1-9.

Hershko C, Graham G, Bates GW, Rachmilewitz EA. 1978. Non-specific serum iron in thalassaemia: An abnormal serum iron fraction of potential toxicity. Br J Haematol 40: $255-263$.

Hershko C, Link G, Konijn AM, Cabantchik ZI. 2005. Objectives and mechanism of iron chelation therapy. Ann NY Acad Sci 1054: 124-135.

Italia KY, Jijina FJ, Merchant R, Panjwani S, Nadkarni AH, Sawant PM, Nair SB, Ghosh K, Colah RB. 2009. Response to hydroxyurea in $\beta$ thalassemia major and intermedia: Experience in western India. Clin Chim Acta 407: 10-15.

Kan YW, Nathan DG. 1970. Mild thalassemia: The result of interactions of $\alpha$ and $\beta$ thalassemia genes. J Clin Invest 49: 635-642.

Karimi M, Haghpanah S, Farhadi A, Yavarian M. 2011. Genotype-phenotype relationship of patients with $\beta$-thalassemia taking hydroxyurea: A 13-year experience in Iran. Int J Hematol 95: 51-56.

Khandros E, Weiss MJ. 2010. Protein quality control during erythropoiesis and hemoglobin synthesis. Hematol Oncol Clin N Am 24: 1071-1088.

Khandros E, Thom CS, D'Souza J, Weiss MJ. 2011. Integrated protein quality control pathways degrade free $\alpha$ globin in $\beta$-thalassemia. Blood 119: 5265-5275.

Kim D, Jensen JH, Wu EX, Feng L, Au WY, Cheung JS, Ha SY, Sheth SS, Brittenham GM. 2011. Rapid monitoring of iron-chelating therapy in thalassemia major by a new carciovascular MR measure: The reduced transverse relaxation rate. NRM Biomed 24: 771-777.

Kong Y, Zhou S, Kihm A, Katein AM, Yu X, Gell DA, Mackay JP, Adachi K, Foster-Brown L, Louden CS, et al. 2004. Loss of $\alpha$-hemoglobin-stabilizing protein impairs erythropoiesis and exacerbates $\beta$-thalassemia. J Clin Invest 114: 1457-1466.

Labie D, Pagnier J, Lapoumeroulie C, Rauabhi F, DundaBelkhodja O, Chardin P, Beldjord C, Wajcman $\mathrm{H}$ Fabry ME, Nagel RL. 1985. Common haplotype dependency of high $\mathrm{G} \gamma$-globin gene expression and high $\mathrm{HbF}$ levels in $\beta$-thalassemia and sickle cell anemia patients. Proc Natl Acad Sci 82: 2111-2114.

Lai MI, Jiang J, Silver N, Best S, Menzel S, Mijovic A, Colella S, Ragoussi J, Garncer C, Weiss MJ, et al. 2006. $\alpha$-haemoglobin stabilizing protein is a quantitative trait gene that modifies the phenotype of $\beta$-thalassaemia. $\mathrm{BrJ}$ Haematol 133: 675-682.

Leung TF, Chu Y, Lee Y, Cheng FW, Leung WK, Shing MM, Li CK. 2009. Long-term effects of pamidronate in thalassemic patients with severe bone mineral density deficits. Hemoglobin 33: 361-369.

Liuzzi JP, Avdemir F, Nam H, Knutson MD, Cousins RJ. 2006. Zip 14 (Slc39a14) mediates non-transferrin-bound iron uptake into cells. Proc Natl Acad Sci 103: 1361213617.

Mancuso A. 2010. Hepatocellular carcinoma in thalassemia: A critical review. World J Hepatol 2: 171-174.

Mathias LA, Fisher TC, Zeng L, Meiselman HJ, Weinberg KI, Hiti AL, Malik P. 2000. Ineffective erythropoiesis in $\beta$ - 
A.W. Nienhuis and D.G. Nathan

thalassemia major is due to apoptosis at the polychromatophilic normoblast stage. Exp Hematol 28: $1343-$ 1353.

Morris CR, Vichinsky EP. 2010. Pulmonary hypertension in thalassemia. Ann NY Acad Sci 1202: 205-213.

Morris CR, Kim HY, Trachtenberg F, Wood J, Quinn CT, Sweeters N, Kwiatkowski JL, Thompson AA, Giardina PJ, Boudreaux J, et al. 2011. Risk factors and mortality associated with an elevated tricuspid regurgitant jet velocity measured by Doppler-echocardiography in thalassemia: A thalassemia clinical research network report. Blood 18: 3794-3802.

Musallam KM, Sankaran VG, Cappellini MD, Duca L, Nathan DG, Taher AT. 2012. Fetal hemoglobin levels and morbidity in untransfused patients with $\beta$-thalassemia intermedia. Blood 119: 364-367.

Nathan DG, Gunn RB. 1966. Thalassemia: The consequences of unbalanced hemoglobin synthesis. Am J Med 4: 815-830.

Nathan DG, Stossel TB, Gunn RB, Zarkowsky HS, Laforet MT. 1969. Influence of hemoglobin precipitation on erythrocyte metabolism in $\alpha$ and $\beta$ thalassemia. J Clin Invest 48: 33-41.

Nemeth E. 2010. Hepcidin in $\beta$-thalassemia. Ann NY Acad Sci 1202: $31-35$.

Nemeth E, Tuttle MS, Powelson J, Vaughn MB, Donovan A, Ward DM, Ganz T, Kaplan J. 2004. Hepcidin regulates cellular iron efflux by binding to ferroportin and inducing its internalization. Science 306: 2051-2053.

Noetzli LJ, Mittelman SD, Watanabe RM, Coates TD, Wood JC. 2011. Pancreatic iron and glucose dysregulation in thalassemia major. Am J Hematol doi: 10.1002/ ajh.22223.

Olivieri NF, Nathan DG, MacMillan JH, Wayne AS, Liu PP, McGee A, Martin M, Koren G, Cohen AR. 1994. Survival in medically treated patients with homozygous $\beta$-thalassemia. N Engl J Med 331: 574-578.

Olivieri NF, Muraca GM, O’Donnell A, Premawardhena A, Fisher C, Weatherall DJ. 2008. Studies in haemoglobin E $\beta$-thalassaemia. Br J Haematol 141: 388-397.

Olivieri NF, Pakbaz Z, Vichinsky E. 2010a. HbE/ $\beta$-thalassemia: Basis of marked clinical diversity. Hematol Oncol Clin North Am 24: 1055-1070.

Olivieri NF, Thayalsuthan V, O'Donnell A, Premawardhena A, Rigobon C, Muraca G, Fisher C, Weatherall DJ. 2010b. Emerging insights in the management of hemoglobin $\mathrm{E} \beta$ thalassemia. Ann NY Acad Sci 1202: 155-157.

Orkin SH, Kazzazian HH Jr, Antonarakis SE, Oster H, Goff SC, Sexton JP. 1982. Abnormal RNA processing due to the exon mutation of $\beta$ E-globin gene. Nature 300: $768-769$.

Oudit GY, Sun H, Trivieri MG, Koch SE, Dawood F, Ackerley C, Yazdanpanah M, Wilson GJ, Schwartz A, Liu PP, et al. 2003. L-type $\mathrm{Ca}^{2+}$ channels provide a major pathway for iron entry into cardiomyocytes in iron-overload cardiomyopathy. Nat Med 9: 1187-1194.

Oudit GY, Trivieri MG, Khaper N, Liu PP, Backx PH. 2006. Role of L-type $\mathrm{Ca}^{2+}$ channels in iron transport and ironoverload cardiomyopathy. J Mol Med (Berl) 84: 349-364.

Pennell DJ, Porter JB, Cappellini MD, El-Beshlawy A, Chan LL, Aydinok Y, Elalfy MS, Sutcharitchan P, Li CK,
Ibrahim H, et al. 2010. Efficacy of deferasirox in reducing and preventing cardiac iron overload in $\beta$-thalassemia. Blood 115: 2364-2371.

Pennell DJ, Porter JB, Cappellini MD, Chan LL, ElBeshlawy A, Aydinok Y, Ibrahim H, Li CK, Viprakasit V, Elalfy MS, et al. 2011. Continued improvement in myocardial $\mathrm{T}^{*}$ over two years of deferasirox therapy in thalassemia major patients with cardiac iron overload. Haematologica 96: 48-54.

Pippard MJ, Callender ST, Weatherall DJ. 1978. Intensive iron-chelation therapy with desferrioxamine in iron loading patients. Clin Sci Mol Med 54: 99-106.

Pirastu M, Kan YW. 1984. Multiple mutations produce $\delta \beta^{0}$ thalassemia in Sardinia. Science 223: 929-930.

Pootrakul P, Breuer W, Sametband M, Sirankapracha P, Hershko C, Cabantchik ZI. 2004. Labile plasma iron (LPI) as an indicator of chelatable plasma redox activity in iron-overloaded $\beta$-thalassemia/HbE patients treated with an oral chelator. Blood 104: 1504-1510.

Porter JB, Abeysinghe RD, Marshall L, Hider RC, Singh S. 1996. Kinetics of removal and reappearance of non-transferrin-bound plasma iron with deferoxamine therapy. Blood 88: 705-713.

Premawardhena A, Fisher CA, Olivieri NF, de Silva S, Sloane-Stanley J, Wood WG, Weatherall DJ. 2005. A novel molecular basis for $\beta$ thalassemia intermedia poses new questions about its pathophysiology. Blood 106: 32513255.

Premawardhena A, Arambepola M, Katugaha N, Weatherall DJ. 2008. Is the $\beta$ thalassaemia trait of clinical importance? Br J Haematol 141: 407-410.

Preza GC, Ruchala P, Pinon R, Ramos E, Qiao B, Perallta MA, Sharma S, Waring G, Ganz T, Nameth E. 2011. Minihepcidins are rationally designed small peptides that mimic hepcidin activity in mice and may be useful for treatment of iron overload. J Clin Invest 121: $4880-4888$.

Propper RD, Shurin SB, Nathan DG. 1976. Reassessment of the use of desferrioxamine B in iron overload. $N$ Engl J Med 294: 1421-1423.

Propper RD, Cooper B, Rufo RR, Nienhuis AW, Anderson WF, Burn HF, Rosenthal A, Nathan DG. 1977. Continuous subcutaneous administration of deferoxamine in patients with iron overload. N Engl J Med 25: 418-423.

Rachmilewitz EA, Giardina PJ. 2011. How I treat thalassemia. Blood 118: 3479-3488.

Rund D, Rachmilewitz E. 2005. $\beta$-Thalassemia. N Engl J Med 353: 1135-1146.

Sankaran VG, Nathan DG. 2010. Thalassemia: An overview of 50 years of clinical research. Hematol Oncol N Am 24: 1005-1020.

* Sankaran VG, Orkin SH. 2013. The switch from fetal to adult hemoglobin. Cold Spring Harb Perspect Med doi: 10.1101/cshperspect.a011643.

Sankaran VG, Xu J, Ragoczy T, Ippolito GC, Walkley CR, Maika SD, Fujiwara Y, Ito M, Groudine M, Bender MA et al. 2009. Developmental and species-divergent globin switching are driven by BCL11A. Nature 460: $1093-$ 1097.

Sankaran VG, Xu J, Byron R, Greisman HA, Fisher C, Weatherall DJ, Sabath DE, Groudine M, Orkin SH, 
Premawardhena A, et al. 2011. A functional element necessary for fetal hemoglobin silencing. N Engl J Med 365: 807-814.

St Pierre TG, Clark PR, Chua-Anusom W, Fleming AJ, Jeffrey GP, Olynyk JK, Pootrakul P, Robins E, Lindeman R. 2005. Noninvasive measurement and imaging of liver iron concentrations using proton magnetic resonance. Blood 105: 855-861.

Taher AT, Musallam KM, Cappellini MD, Weatherall DJ. 2011. Optimal management of $\beta$ thalassaemia intermedia. Br J Haematol 152: 512-523.

Tanner MA, Galanello R, Dessi C, Smith GC, Westwood MA, Agus A, Roughton M, Assomull R, Nair SV, Walker JM, et al. 2007. A randomized, placebo-controlled, double-blind trial of the effect of combined therapy with deferoxamine and deferiprone on myocardial iron in thalassemia major using cardiovascular magnetic resonance. Circulation 115: 1876-1884.

Tanno T, Bhanu NV, Oneal PA, Goh SH, Staker P, Lee YT, Moroney JW, Reed CH, Luban NL, Wang RH, et al. 2007. High levels of GDF15 in thalassemia suppress expression of the iron regulatory protein hepcidin. Nat Med 13: 1096-1101.

Tanno T, Porayette P, Sripichai O, Noh SJ, Byrnes C, Bhupatiraju A, Lee YT, Goodnough JB, Harandi O, Ganz T, et al. 2009. Identification of TWSG1 as a second novel erythroid regulator of hepcidin expression in murine and human cells. Blood 114: 181-186.

Tassiopoulos S, Deftereos S, Konstantopoulos K, Farmakis D, Tsironi M, Kyriakdis M, Aessopos A. 2005. Does heterozygous $\beta$-thalassemia confer a protection against coronary artery disease? Ann NY Acad Sci 1054: 467-470.

Terpos E, Voskaridou E. 2010. Treatment options for thalassemia patients with osteoporosis. Ann NY Acad Sci 1202: $237-243$.

Thein SL. 1999. Is it dominantly inherited $\beta$ thalassemia or just a $\beta$-chain variant that is highly unstable? $\mathrm{Br} \mathrm{J} \mathrm{Hae}$ matol 107: 12-21.

* Thein SL. 2013. Molecular basis of $\beta$ thalassemia. Cold Spring Harb Perspect Med doi: 10.1101/cshperspect. a011700.

Uda M, Galanello R, Sanna S, Lettre G, Sankaran VG, Chen W, Usala G, Busonero F, Maschio A, Albai G, et al. 2008. Genome-wide association study shows BCL11A associated with persistent fetal hemoglobin and amelioration of phenotype of $\beta$-thalassemia. Proc Natl Acad Sci 105: 1620-1625.

Wainscoat JS, Kanavakis E, Wood WG, Letsky EA, Huehns ER, Marsh GW, Higgs DR, Clegg JB, Weatherall DJ. 1983. Thalassaemia intermedia in Cyprus: The inter-
Pathophysiology of $\beta$-Thalassemia Syndromes

action of $\alpha$ and $\beta$ thalassaemia. Br J Haematol 53: 411-416.

Weatherall DJ. 2001. Phenotype-genotype relationships in monogenic disease: Lessons from the thalassemias. Nat Rev Genet 2: 245-255.

Weatherall DJ, Clegg JB. 2001. The thalassemia syndromes, 4th ed. Blackwell Science, Oxford.

Weatherall DJ, Clegg JB, Naughton MA. 1965. Globin synthesis in thalassemia: An in vitro study. Nature 208: $1061-1065$.

Weiss MJ, dos Santos CO. 2009. Chaperoning erythropoiesis. Blood 113: 2136-2144.

White JM, Richards R, Byrne M, Buchanan T, White YS, Jelenski G. 1985. Thalassemia trait and pregnancy. J Clin Pathol 38: 810-817.

Wilber A, Hargrove PW, Kim YS, Riberdy JM, Sankaran VG, Papanikolaou E, Georgomanoli M, Anagnou NP, Orkin SH, Nienhuis AW, et al. 2011a. Therapeutic levels of fetal hemoglobin in erythroid progeny of $\beta$-thalassemic $\mathrm{CD}_{3}{ }^{+}$cells after lentiviral vector-mediated gene transfer. Blood 117: 2817-2826.

Wilber A, Nienhuis AW, Persons DA. 2011b. Transcriptional regulation of fetal to adult hemoglobin switching: New therapeutic opportunities. Blood 117: 3945-3953.

Wolfe L, Olivieri N, Sallan D, Colan S, Rose V, Propper R, Freedman MH, Nathan DG. 1985. Prevention of cardiac disease by subcutaneous deferoxamine in patients with thalassemia major. N Engl J Med 312: 1600-1603.

Wood JC. 2011. Impact of iron assessment by MRI. Hematology Am Soc Hematol Educ Program 2011: 443-450.

Wu EX, Kim D, Tosti CL, Tang H, Jensen JH, Cheung JS, Feng L, Au WY, Ha SY, Sheth SS, et al. 2010. Magnetic resonance assessment of iron overload by separate measurement of tissue ferritin and hemosiderin iron. Ann NY Acad Sci 1202: 115-122.

Xu J, Peng C, Sankaran VG, Shao Z, Esrick EB, Chong BG, Ippolito GC, Fujiwara Y, Ebert BL, Tucker PW, et al. 2011. Correction of sickle cell disease in adult mice by interference with fetal hemoglobin silencing. Science 334: 993996.

Yu X, Kong Y, Dore LC, Abdulmalik O, Katein AM, Zhou S, Choi JK, Gell D, Mackay JP, Gow AJ, et al. 2007. An erythroid chaperone that facilitates folding of $\alpha$-globin subunits for hemoglobin synthesis. J Clin Invest 117: 1856-1865.

Yu X, Mollan TL, Butler A, Gow AJ, Olson JS, Weiss MJ. 2009. Analysis of human $\alpha$ globin gene mutations that impair binding to the $\alpha$ hemoglobin stabilizing protein. Blood 113: 5961-5969. 


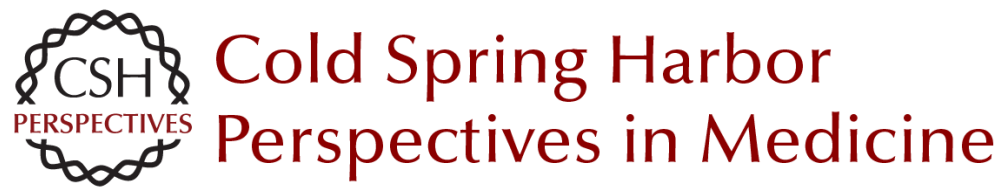

\title{
Pathophysiology and Clinical Manifestations of the $\beta$-Thalassemias
}

\author{
Arthur W. Nienhuis and David G. Nathan
}

Cold Spring Harb Perspect Med 2012; doi: 10.1101/cshperspect.a011726

Subject Collection Hemoglobin and Its Diseases

The Natural History of Sickle Cell Disease Graham R. Serjeant

Current Management of Sickle Cell Anemia Patrick T. McGann, Alecia C. Nero and Russell E. Ware

Cell-Free Hemoglobin and Its Scavenger Proteins: New Disease Models Leading the Way to Targeted Therapies Dominik J. Schaer and Paul W. Buehler

Clinical Manifestations of $\alpha$-Thalassemia Elliott P. Vichinsky

Erythroid Heme Biosynthesis and Its Disorders Harry A. Dailey and Peter N. Meissner

Hemoglobin Variants: Biochemical Properties and Clinical Correlates Christopher S. Thom, Claire F. Dickson, David A. Gell, et al.

The Prevention of Thalassemia Antonio Cao and Yuet Wai Kan

The Switch from Fetal to Adult Hemoglobin Vijay G. Sankaran and Stuart H. Orkin

\author{
Transcriptional Mechanisms Underlying \\ Hemoglobin Synthesis \\ Koichi R. Katsumura, Andrew W. DeVilbiss, \\ Nathaniel J. Pope, et al.
}

Iron Deficiency Anemia: A Common and Curable

Disease Jeffery L. Miller

Management of the Thalassemias Nancy F. Olivieri and Gary M. Brittenham

The Molecular Basis of $\beta$-Thalassemia Swee Lay Thein

Erythropoiesis: Development and Differentiation Elaine Dzierzak and Sjaak Philipsen

Erythropoietin

H. Franklin Bunn

Classification of the Disorders of Hemoglobin Bernard G. Forget and H. Franklin Bunn

The Molecular Basis of $\alpha$-Thalassemia Douglas R. Higgs

For additional articles in this collection, see http://perspectivesinmedicine.cshlp.org/cgi/collection/ 